Article

\title{
Seasonality and Nutrition-Sensitive Agriculture in Kenya: Evidence from Mixed-Methods Research in Rural Lake Naivasha Basin
}

\author{
Maria Sassi (D) \\ Department of Economics and Management, University of Pavia, Via S. Felice 5, 27100 Pavia, Italy; \\ maria.sassi@unipv.it; Tel.: +39-0382986465
}

Received: 10 October 2019; Accepted: 3 November 2019; Published: 7 November 2019

\begin{abstract}
This study investigates the impact of seasonality within the debate on nutrition-sensitive agriculture focusing on rural Lake Naivasha Basin in Kenya, which presents an interesting case study of the food system in East Africa. Seasonality shapes food and nutrition security in sub-Saharan Africa, dominated by a rain-fed system; however, lack of monthly data hampers understanding. Using mixed methods, this study constructs a monthly dataset of a representative sample of households from February 2018 to January 2019. A fixed-effects analysis highlights the association between three pathways from agriculture to nutrition while controlling for the hunger and harvesting seasons by crop. Supported by qualitative information from focus groups, the results suggest that seasonality is an important dimension of the agriculture-nutrition link and promote understanding of the complexity of the pathways suggested by the literature, including the association between crops and dietary diversity, with relevant policy implications.
\end{abstract}

Keywords: seasonality; nutrition-sensitive agriculture; mixed methods; Lake Naivasha basin; Kenya

\section{Introduction}

A growing number of governments, donor agencies, and development organisations are recognising nutrition-sensitive development as a key approach to improve food and nutrition security [1]. In this context, agriculture makes a vital contribution, especially in sub-Saharan Africa where a large part of the population depends on the sector as a major source of food and livelihood. Nutrition-sensitive agriculture is a food-based approach to the development of the sector that seeks to maximise agriculture's contribution to nutrition, going beyond food production to address underlying and basic causes of malnutrition [2].

At the global level, the United Nations' 2030 Agenda for Sustainable Development [3] has recognised this role of the agricultural sector with the Zero Hunger Challenge. At the regional level, a growing number of initiatives, such as the Comprehensive Africa Agriculture Development Programme Investment Plans, support nutrition-sensitive agriculture in sub-Saharan African countries [4,5]. Moreover, an extensive body of literature that links agriculture to food and nutrition security has also developed in recent years. However, while there is consensus on the conceptual frameworks that identify the multiple pathways by which agriculture can affect nutrition, empirical evidence remains weak and presents several gaps [6]. This evidence would be of special importance when seeking a strategy to improve food security.

Our study covers some of the gaps in the available empirical studies. Among them, one of the most important is the need for a longitudinal design $[7,8]$. The majority of studies use cross-sectional data. Therefore, results may be over- or underestimated due to confounding bias. The inclusion of time-variant factors is especially important in sub-Saharan countries where seasonality shapes food 
and nutrition security $[9,10]$. In these countries, most crops are grown using a rain-fed agricultural system while irrigation is limited to a small minority of households. Moreover, children experience food shortage and decline in caloric consumption during the lean season $[10,11]$. There is also evidence of an increase in household dietary diversity during the hunger season and of considerable variability in dietary diversity between the post- and pre-harvesting periods [12,13]. Despite these studies, the evidence on nutrition-sensitive agriculture generated from panel data is scant and, to the best of our knowledge, no empirical investigations use monthly data. The scant panel models in the literature refer to rounds administered over a one-year period and very few consider the pre- and post-harvest periods. These studies do not reflect the household situation throughout the year. On the other hand, the preand post-harvest studies select the seasons based on the most important staple food produced; as such, they neglect the role of other food items in food and nutrition security. Therefore, the association of food and nutrition security with increasing food production diversity and availability over the year is not fully investigated, thereby resulting in loss of important information for redesigning policies and interventions related to food security.

This study attempts to uncover these areas and to present a more accurate investigation of the pathways that link agriculture to the household food consumption status based on a panel data with monthly observations over a period of a year. Our observational study aims to unveil or confirm associations between three of the pathways through which agriculture affects nutrition as hypothesized by the literature, namely food, income, and women's empowerment, while controlling for two types of seasonality, that is, the hunger season and the harvesting season by crop.

The fixed-effect model used in this study also addresses potential endogeneity problems arising from two unobserved issues: the possible time-constant heterogeneity across observations and time-varying factors that affect all households similarly [14]. Cross-sectional studies do not consider these problems with possible estimation bias.

Our mixed-methods research includes the construction of a rare monthly dataset, comprising a statistically representative sample of 606 households from February 2018 to January 2019 in the lower and middle basin of Lake Naivasha in Kenya, and integrated with qualitative information collected through focus group discussions. The rural area surrounding Lake Naivasha offers an interesting case study because it presents the features of the food system promoted in East Africa: market-based commercial agriculture in areas where poverty and food insecurity are widespread and where agriculture is the major source of food and livelihood for the population [15]. In the Lake Naivasha Basin, a dominating large floriculture sector coexists with a system of smallholder farms, mainly owned by Kenyans, which produces vegetables for the local market with low technology [16].

Therefore, this study, while contributing to the general literature on nutrition-sensitive agriculture, is a useful case study on an under-researched area of the food system. Moreover, this level of investigation, which is rarely undertaken by empirical studies, is of specific importance for policymaking. As noted by Ruel et al. [5], the local context plays a key role in understanding pathways from agriculture to nutrition due, for example, to the influence of diversity in the local market on these transmission channels, an aspect that the majority of the literature refers to as country-level masks.

The structure of the paper is as follows. Section 2 presents the theoretical framework adopted and the variables selected. Section 3 illustrates the methodology used for data collection and estimation. Section 4 presents and discusses results. Section 5 concludes.

\section{Theoretical Framework and Variable Selection}

The literature agrees that agriculture affects nutrition as a source of food and income, an influencer of food prices, and an entry-point for enhancing women's empowerment [17]. Figure 1 provides a representation of these pathways using the theory of a change map. The pass-through channels have been adapted to better reflect the focus of our analysis and the boxes shaded in grey represent the impacts and outputs investigated in this study. 


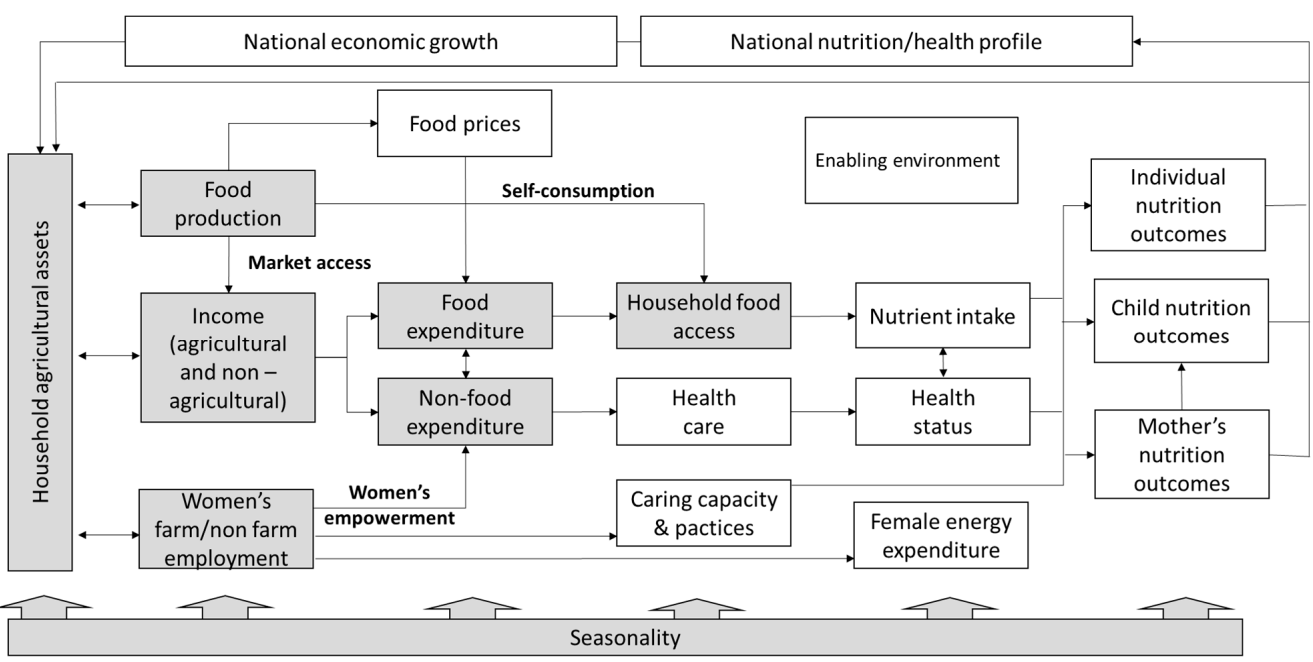

Figure 1. Conceptual framework of the pathways and links between agriculture and nutrition outcomes. Source: adapted from [18].

Our study focuses on three pathways suggested by the literature. The first considers agriculture as a direct source of food at the household level. This is the path whereby food access is driven by own production primarily due to market imperfections. The non-separability of production and consumption decisions due to the incompleteness of markets also creates the potential for farm productive assets to have a direct dietary impact on nutrition [19]. For this reason, this group of variables has also been included in our analysis. Next, food production sale on the market is an alternative use. Therefore, the second pathway we considered focuses on agriculture as an indirect source of household food and nutrition-relevant non-food expenditure (i.e., health and education) via the income effect from the sale of commodities produced or wages earned. The third transmission pathway links household access to food to women's empowerment due to farm and non-farm employment, through expenditure on food and non-food items.

As previously mentioned our empirical analysis includes seasonality in terms of the effects of the hunger season and harvesting season on food access. This is a new element introduced in the consolidated theoretical approach by our study, and is justified based on its effects on the different pathways from agriculture to nutrition.

Based on these considerations, we selected the Food Consumption Score (FCS) as the impact variable and the eight categories of explanatory variables are listed in Table 1 with their descriptive statistics. All variables are time-variant.

Table 1. Descriptive statistics of variables.

\begin{tabular}{ccccc}
\hline Variable & Mean & Standard Deviation & Minimum & Maximum \\
\hline Food Consumption Score (FCS) & 74.626 & 15.559 & 6 & 112 \\
\hline & Crop production & & & \\
\hline Number of crops harvested & 1.513 & 1.278 & 0 & 7 \\
\hline & Household agricultural assets & & \\
\hline Production assets index & 0.001 & 0.855 & -1.117 & 3.218 \\
Input use & 0.109 & 0.311 & 0 & 1 \\
Savings & 0.110 & 0.314 & 0 & 1 \\
HH size (adult equivalent) & 2.126 & 0.804 & 1 & 5 \\
HH Dependency ratio & 39.708 & 29.301 & 0 & 100 \\
Age & 48.040 & 16.407 & 16 & 94 \\
Gender & 0.303 & 0.459 & 0 & 1 \\
Literacy & 0.881 & 0.323 & 0 & 1 \\
Marital status & 0.645 & 0.478 & 0 & 1 \\
Health status & 0.145 & 0.352 & 0 & 1 \\
\hline
\end{tabular}


Table 1. Cont.

\begin{tabular}{|c|c|c|c|c|}
\hline Variable & Mean & Standard Deviation & Minimum & Maximum \\
\hline \multicolumn{5}{|c|}{ Use of crop production } \\
\hline Self-consumption & 0.091 & 0.222 & 0 & 6 \\
\hline Market access & 0.101 & 0.651 & 0 & 33.333 \\
\hline Market access Maize & 0.020 & 0.155 & 0 & 11.111 \\
\hline Market access Beans & 0.022 & 0.419 & 0 & 29.167 \\
\hline Market access Potatoes & 0.010 & 0.068 & 0 & 4.167 \\
\hline Market access Other crops & 0.013 & 0.072 & 0 & 1.000 \\
\hline \multicolumn{5}{|c|}{ Total income } \\
\hline Income first quantile & 0.200 & 0.400 & 0 & 1 \\
\hline Income second quantile & 0.199 & 0.399 & 0 & 1 \\
\hline Income third quantile & 0.200 & 0.400 & 0 & 1 \\
\hline Income fourth quantile & 0.199 & 0.399 & 0 & 1 \\
\hline Income fifth quantile & 0.199 & 0.399 & 0 & 1 \\
\hline \multicolumn{5}{|c|}{ Non-farm income } \\
\hline $\begin{array}{l}\text { N. HH members employed in } \\
\text { off-farm agric. sectors }\end{array}$ & 0.565 & 0.719 & 0 & 4 \\
\hline $\begin{array}{l}\text { N. HH members employed in } \\
\text { off-farm non-agric. sectors }\end{array}$ & 0.564 & 0.786 & 0 & 5 \\
\hline \multicolumn{5}{|c|}{ Women's empowerment } \\
\hline $\begin{array}{l}\text { N. women employed in off-farm } \\
\text { agric. Sectors }\end{array}$ & 0.699 & 0.704 & 0 & 4 \\
\hline $\begin{array}{l}\text { N. woman employed in off-farm } \\
\text { non-agric. Sectors }\end{array}$ & 0.791 & 0.773 & 0 & 5 \\
\hline \multicolumn{5}{|c|}{ Use of income } \\
\hline Log food expenditure & 6.542 & 1.078 & 0 & 11.135 \\
\hline Log non-food expenditure & 7.222 & 0.975 & 0 & 11.861 \\
\hline Price index & 67.024 & 14.754 & 10 & 152.857 \\
\hline \multicolumn{5}{|c|}{ Seasonality } \\
\hline Hunger season & 0.25 & 0.433 & 0 & 1 \\
\hline Maize harvesting & 0.204 & 0.4032 & 0 & 1 \\
\hline Potatoes harvesting & 1.465 & 0.353 & 0 & 1 \\
\hline Beans harvesting & 0.259 & 0.438 & 0 & 1 \\
\hline Other crops harvesting & 0.903 & 1.125 & 0 & 1 \\
\hline
\end{tabular}

Note: $\mathrm{HH}=$ household. Source: author's elaboration based on primary sources of data.

The literature frequently uses household dietary diversity score measures as the outcome variable to assess the nutritional adequacy of agricultural pathways. Empirical evidence on the positive association between dietary diversity and a high-quality diet supports the appropriateness of these indicators [20]. A large number of studies define dietary diversity as the number of different food groups or items over a given recall period. However, these measures present many limitations. Compared to a food-group based indicator, a food-item-based dietary diversity indicator tends to be a weaker predictor of nutritional adequacy [14]. The food items count increases with the increase in the number of foods consumed even when they are of the same food groups and particularly of the micronutrient-poor food groups, therefore, adding little nutritional value to the diet. In addition, both the food group-based and food item-based indicators do not capture differences in the distribution of consumption because food groups or items are all equally weighted [21].

To overcome these problems, our study employs the FCS as the outcome variable, based on 7-days recall data. The FCS is a composite indicator, which combines data on dietary diversity, food frequency, and relative nutritional importance [22]. Therefore, it is a more accurate proxy of the usual calorie content of the household diet pattern. Following the World Food Programme (WFP) protocol [23], we classified the food items consumed at the household level into eight food groups. Next, we multiplied the consumption frequency of each of these by a standard weight based on the 
specific energy, protein, and micronutrients provided. Finally, we computed the household FCS by summing up these values. Following Jones et al. [24], we used the continuous FCS variable instead of the standard three-level categorical variable. This choice allowed us to prevent data loss.

The FCS has some limitations that need to be highlighted in nutrition-sensitive agriculture analysis for a correct interpretation of results. Validation studies have demonstrated that the FCS is associated with household caloric availability $[25,26]$, but it has not been validated against the adequacy of macronutrients or micronutrients [8]. Therefore, it should be interpreted with caution as an indicator of nutrition security. Moreover, as indicated in Sassi [22], by aggregating household-level data, the FCS does not capture intra-household food consumption; therefore, it is not an appropriate measure for interventions targeting individual nutrition security, especially of the vulnerable categories including women and children.

\section{Explanatory Variables}

As the literature recognises the positive association between crop diversification and nutrition diversity [5], the first set of explanatory variables used in our analysis includes the number of crops harvested by household and month and its squared value to capture a possible non-linear association between agricultural diversity and the FCS. We could not use the other measures of crop diversification suggested by some studies, such as the Simpson Diversity Index or the Ogive Index, because of the difficulty in estimating the amount of land used per crop. Specifically, the investigated area makes widespread use of multiple cropping systems. Therefore, it was not possible to isolate the information on land use by crop. However, recent studies show the consistency of the simple count measure of farm diversification with the alternative measures of farm diversity $[21,27,28]$.

The second group of variables adopted includes the households' agricultural assets, in terms of a productive assets index, input use, intangible productive assets, and human capital endowment. We first used the polychoric principal components analysis (PCA) to compute the productive assets index. The questionnaire design comprised interviewing relevant stakeholders to validate its individual parts. Regarding production activities, the stakeholders suggested including small stocks (such as goats), ploughs, small businesses, hoes, granaries, and oxcarts as assets. We included all these items in the polychoric PCA after confirming the sampling adequacy. To this end, we first applied the Bartlett test of sphericity and obtained a $p$-value of 0.000 , indicating the validity of the technique adopted. The Kaiser-Meyer-Olkin test of sampling adequacy yielded a value of 0.586 and confirmed this result. Finally, the determinant of the correlation matrix was 0.7 , suggesting that not all correlations equal 0 .

A second variable in the category of households' agricultural assets is input use, which is a dummy variable that takes on values 0 or 1 to indicate the absence or presence of agricultural factors of production, respectively, such as seeds, pesticides, fertilisers, and other inputs. Next, we represented the intangible productive assets by the variable savings, computed as a dummy variable that is equal to 1 if the household saves money and 0 otherwise.

Following the literature, we first included among the human capital endowment components the gender, marital status, age, and literacy of the household head [27]. The gender and marital status of the household head capture possible greater barriers to assets and income faced by female-headed households and households with an unmarried head, in comparison to the other households. We constructed the household head's gender as a dummy variable that equals 1 if the head is male and 0 if the head is female. Additionally, we created an artificial variable for the household head's marital status, which equals 1 if the household head is married and 0 if the head is single, divorced, separated, or widowed.

We used the age in years of the household heads as a proxy of their experience in agriculture, and literacy as a proxy for their attitude being more innovative. We introduced a dummy variable equal to 1 if the household head was literate and 0 otherwise to represent literacy. We considered as literate a person aged 15 and over who declared being able to read and write regardless of his/her level of education. 
In the human capital endowment category, we also included two other variables to capture labour availability within the household, which is especially important in the labour-intensive farming systems typical of rural African areas. The first variable considered was the adult equivalent household size, taking reference from the scale proposed by [29], namely the 'OECD-modified scale', to compute this variable. Accordingly, we assign a value of 1 to the household head, 0.5 to each additional adult member, and 0.3 to each child. Next, the values associated with each household member are aggregated to compute the adult equivalent household size.

The second indicator adopted was the household dependency ratio, computed as the number of members who declared themselves to be unemployed and hence, dependent on the working population, that is, those who declared that they were employed in the specific month under investigation. Using this indicator instead of the proportion of the population not in the workforce over the working age population is more appropriate for the monthly-based investigations conducted in the African context. In fact, it facilitates capturing the effect of specific phenomena such as casual and child labour.

As suggested by the literature, the health of family members may affect farm productivity [30]. For this reason, as the last variable in the category of human capital endowment, we introduced household health status as a dummy explanatory variable that takes on a value of 0 or 1 to indicate the absence or presence of at least one member with a permanent/chronic disease or health problem.

As far as crop use is concerned, we included in our analysis a crop self-consumption index to capture the pathway that considered agriculture as a direct source of food. We calculated this index as a share of the amount of crops consumed over those produced.

Similarly, we measured the market access for crops produced as a share of the total amount of crops sold over the quantity of crops produced. We used this index based on several considerations. First, several studies show that commercialisation, especially of smallholder farmers, is determined by market participation [31,32]. Therefore, farm commercialisation is a more appropriate variable to assess the pathways between crops and nutrition than the proxy variables traditionally used in the literature, such as the measures of distance to a major road or population centre or the ownership of transportation means, which indicates only the potential access to markets. We also distinguished between the market access of the most high-value crops, that is, maize, potatoes, and beans, and of the other crops including the remaining local crops. This latter category, comprising almost 20 crops, includes a large number of cereals, pulses, and vegetables. However, households produce a limited number of them. We measured the market access for these categories of crops through an index computed as the amount of the single crop sold over its production.

The literature suggests that agricultural commercialisation is more important than crop diversification for improving nutrition and dietary diversification [28]. To account for this possible effect, we included the interaction between the number of crops harvested and market access.

Concerning income, we considered total income and non-farm income. For total income, we used the natural logarithm of total expenditure on both food and non-food items in Kenyan shillings (KSh) per adult equivalent and disaggregated it into quantiles to distinguish five different categories of households: the very poor, poor, middle, rich, and very rich. We created an artificial variable for each quantile of household income per adult equivalent with the very rich as the base category. The total expenditure in KSh per adult equivalent was disaggregated in food and non-food expenditure and used in the natural logarithm. In the category use of income, we also included the price index computed at the household level and based on the food expenditure.

As the literature recognizes income from non-farm activities as an important source of household diet diversification, we constructed two proxy variables. The former is the number of household members employed in off-farm agricultural sectors (crop, fishing, and livestock) while the second counts the number of household members employed in the off-farm non-agricultural sectors (including floriculture). 
We created the same variables only counting the female components of the household as a proxy of women's empowerment. In some studies, women empowerment is measured using gender in decision-making on food purchases. However, in our case, in almost all households, women decide on food purchasing; therefore, we did not include this variable given the lack of variability across units and over time.

Next, we consider the seasonality variables. Hunger season is a dummy variable taking a value of 1 in the months March, April, and May and 0 otherwise. The Ministry of Agriculture of the Nakuru District provided us with this information. We also verified the association between the household FCS and the harvesting season of maize, potatoes, beans, and other crops. For each household, we created an artificial variable equal to 1 when the household harvested the specific crop and 0 otherwise.

\section{Data Collection and Estimation Methodology}

Our mixed methods research involved data collection through a survey with quantitative and qualitative questions and focus group discussions. The triangulation of this information allowed us to better identify and understand several aspects of the investigated phenomena.

The data collection was based on a questionnaire submitted on a monthly basis from February 2018 to January 2019 in the rural lower and middle basin of Lake Naivasha in Kenya. We validated it using the stakeholders from the National Drought Monitoring Authority of the Kenya National Bureau of Statistics (KNBS) in the Nakuru County Office, Ministry of Agriculture Naivasha Sub-county Office, university staff, and a group of enumerators. An expert linguist translated the questionnaire into Kiswahili and Kikuyu, the two most important vernacular languages.

We articulated our survey using the steps suggested by Chocran [33], paying special attention to sample selection and degree of precision. Referring to the methodology adopted by the Kenya National Bureau of Statistics (KNBS) for the selection of the households [34], we selected 606 of the 28,939 households as representative of the rural area of the sub-counties of Gilgil and Naivasha. This number was computed using Cochran's [33] formula. According to Cochran's formula, our sample size should include 588 households. Nonetheless, we preferred a higher number of observations (i.e., 606) to avoid a possible reduction of the sample below the representative level due to events such as household migration to other areas or relocation to the floriculture sector for employment purposes. In Cochran's formula, we used 1.96 as the critical value of the desired confidence level corresponding to a level of confidence of 95 percent. In other words, we accepted a 5 percent probability of error in our estimates. Moreover, we selected a desired margin of error of 4 percent.

The KNBS of Nakuru supported the process of household mapping based on their household clusters in order to select a statistically representative sample.

We used an interviewing process in which the interviewer reads a standard set of questions with no discretion. We adopted the Open Data Kit for data collection through mobile devices. We selected the enumerators among the staff of the KNBS of Nakuru and students of the Nairobi University. We trained them and used them to pilot the questionnaire.

Among others, we included in our questionnaire two qualitative questions concerning the perception of the three most important food insecurity and poverty problems in the village. Additionally, we further developed the qualitative part of our research by organising seven focus group discussions, one for each of the clusters in which the investigated area is organised (Kiburuti, Leleshwa, Ngano-Ini, Gathengera, Lower Nyamathi, Tumaini, and Kanjogu). This qualitative research technique allowed us to obtain in-depth information about the results achieved in the quantitative analysis. Each group comprised a balanced number of elderly women, elderly men, adult women, and adult men, with eight members in all in each group. We also interviewed the community leaders of each cluster separately.

Based on the data collected, we estimated eight individual-specific effects models for the dependent variable FCS. The basic specification is given by the following estimation equation:

$$
F C S_{i t}=\alpha_{i}+x_{i t} \beta+\varepsilon_{i t}
$$


where $i$ refers to the household, $t$ refers to the month, $x_{i t}$ denote the regressors and $\beta$ their respective coefficients, $\alpha_{i}$ are the random individual-specific effects, and $\varepsilon_{i t}$ is the idiosyncratic error term. The Hausman test, reported for all estimates in the Results section, suggested a fixed-effect model for the $\alpha_{i}$. Therefore, our models allowed $\alpha_{i}$ to be correlated with the regressors while assuming $x_{i t}$ was uncorrelated with the idiosyncratic error. These estimates used cluster-robust standard errors.

Concerning regressors, we started from a basic model in which we used the number of crops and its squared value, the price index as representative of the use of income, all the selected variables in the group of household agricultural assets, use of crop production, total income, non-farm income, and the hunger season to control for seasonality. In the second model, we disaggregated market access by crop. In the third model, the variables in the group use of income replaced the income quantiles in the basic model while in the fourth model, we substituted non-farm income in the basic model with the women's empowerment variables. The other four models investigate the harvesting seasons whereby we supplemented the basic model with the harvesting season of maize, beans, potatoes, and other crops instead of the hunger season.

\section{Results and Discussion}

Table 2 shows the results of the first four models while Table 3 includes the harvesting season by crop in Model 1.

Table 2. Fixed effects analysis of determinants of household FCS: Models 1-4.

\begin{tabular}{|c|c|c|c|c|}
\hline Variable & Model 1 & Model 2 & Model 3 & Model 4 \\
\hline \multicolumn{5}{|c|}{ Crop production } \\
\hline Number of crops harvested & $\begin{array}{c}3.460 * * * \\
(0.536)\end{array}$ & $\begin{array}{c}3.429 * * * \\
(0.445)\end{array}$ & $\begin{array}{c}3.433 * * * \\
(0.529)\end{array}$ & $\begin{array}{c}3.577^{* * *} \\
(0.539)\end{array}$ \\
\hline Number of crops harvested squared & $\begin{array}{c}-0.691 \text { *** } \\
(0.128)\end{array}$ & $\begin{array}{c}-0.660^{* * *} \\
(0.110)\end{array}$ & $\begin{array}{c}-0.693^{* * *} \\
(0.127)\end{array}$ & $\begin{array}{c}-0.705^{* * * *} \\
(0.129)\end{array}$ \\
\hline \multicolumn{5}{|c|}{$\mathrm{HH}$ agricultural assets } \\
\hline Production assets index & $\begin{array}{l}1.159 * * \\
(0.500)\end{array}$ & $\begin{array}{c}1.149 * * * \\
(0.396)\end{array}$ & $\begin{array}{l}0.955^{*} \\
(0.491)\end{array}$ & $\begin{array}{l}1.212 \text { ** } \\
(0.501)\end{array}$ \\
\hline Input use & $\begin{array}{l}-1.231 \text { * } \\
(0.687)\end{array}$ & $\begin{array}{c}-1.242^{* *} \\
(0.543)\end{array}$ & $\begin{array}{c}-1.428^{* *} \\
(0.685)\end{array}$ & $\begin{array}{c}-1.162 * \\
(0.687)\end{array}$ \\
\hline Savings & $\begin{array}{c}3.273^{* * *} \\
(0.646)\end{array}$ & $\begin{array}{c}3.287^{* * *} \\
(0.587)\end{array}$ & $\begin{array}{c}2.961^{* * *} \\
(0.644)\end{array}$ & $\begin{array}{c}3.257 * * * \\
(0.649)\end{array}$ \\
\hline $\mathrm{HH}$ size adult equivalent & $\begin{array}{c}-1.790^{* *} \\
(0.754)\end{array}$ & $\begin{array}{c}-1.706^{* * *} \\
(0.621)\end{array}$ & $\begin{array}{c}-1.627^{\text {** }} \\
(0.714)\end{array}$ & $\begin{array}{l}-1.208 \\
(0.763)\end{array}$ \\
\hline Dependency ratio & $\begin{array}{c}0.043 \\
(0.027)\end{array}$ & $\begin{array}{l}0.042 * \\
(0.023)\end{array}$ & $\begin{array}{l}0.044 \text { * } \\
(0.026)\end{array}$ & $\begin{array}{c}0.031 \\
(0.027)\end{array}$ \\
\hline Age & $\begin{array}{c}0.156 \\
(0.227)\end{array}$ & $\begin{array}{c}0.162 \\
(0.227)\end{array}$ & $\begin{array}{c}0.200 \\
(0.235)\end{array}$ & $\begin{array}{c}0.151 \\
(0.223)\end{array}$ \\
\hline Age squared & $\begin{array}{l}-0.003 \\
(0.002)\end{array}$ & $\begin{array}{l}-0.003 \\
(0.002)\end{array}$ & $\begin{array}{l}-0.003 \\
(0.002)\end{array}$ & $\begin{array}{l}-0.003 \\
(0.002)\end{array}$ \\
\hline Gender & $\begin{array}{l}-1.941 \\
(2.438)\end{array}$ & $\begin{array}{l}-1.956 \\
(1.517)\end{array}$ & $\begin{array}{l}-1.938 \\
(2.377)\end{array}$ & $\begin{array}{l}-2.328 \\
(2.401)\end{array}$ \\
\hline Literacy & $\begin{array}{l}4.622 * * * \\
(1.156)\end{array}$ & $\begin{array}{c}4.629 * * * \\
(0.970)\end{array}$ & $\begin{array}{c}4.511^{* * * *} \\
(1.124)\end{array}$ & $\begin{array}{c}4.625^{* * *} \\
(1.151)\end{array}$ \\
\hline Marital status & $\begin{array}{c}0.516 \\
(1.197)\end{array}$ & $\begin{array}{c}0.519 \\
(1.051)\end{array}$ & $\begin{array}{c}0.410 \\
(1.200)\end{array}$ & $\begin{array}{c}0.478 \\
(1.206)\end{array}$ \\
\hline Health status & $\begin{array}{c}-4.112 \text { *** } \\
(0.711)\end{array}$ & $\begin{array}{c}-4.043^{* * *} \\
(0.547)\end{array}$ & $\begin{array}{c}-4.409^{* * *} \\
(0.701)\end{array}$ & $\begin{array}{c}-4.186^{* * *} \\
(0.714)\end{array}$ \\
\hline
\end{tabular}


Table 2. Cont.

\begin{tabular}{|c|c|c|c|c|}
\hline Variable & Model 1 & Model 2 & Model 3 & Model 4 \\
\hline \multicolumn{5}{|c|}{ Use of crop production } \\
\hline Self-consumption & $\begin{array}{l}-1.647^{* *} \\
(0.763)\end{array}$ & $\begin{array}{l}-1.733^{* *} \\
(0.745)\end{array}$ & $\begin{array}{l}-1.606^{* *} \\
(0.761)\end{array}$ & $\begin{array}{l}-1.612^{* *} \\
(0.761)\end{array}$ \\
\hline Market access & $\begin{array}{l}2.951 * \\
(1.575)\end{array}$ & & $\begin{array}{l}2.812 * \\
(1.568)\end{array}$ & $\begin{array}{l}2.917 * \\
(1.571)\end{array}$ \\
\hline Market access maize & & $\begin{array}{l}6.487^{* * *} \\
(1.227)\end{array}$ & & \\
\hline Market access beans & & $\begin{array}{l}2.450 * * \\
(0.854)\end{array}$ & & \\
\hline Market access potatoes & & $\begin{array}{c}2.776 \\
(2.755)\end{array}$ & & \\
\hline Market access other crops & & $\begin{array}{l}-1.334 \\
(2.512)\end{array}$ & & \\
\hline Market access * Number of crops harvested & $\begin{array}{c}-1.040^{* *} \\
(0.528)\end{array}$ & $\begin{array}{c}-0.638^{* *} \\
(0.249)\end{array}$ & $\begin{array}{l}-1.001 * \\
(0.525)\end{array}$ & $\begin{array}{c}-1.024^{*} \\
(0.525)\end{array}$ \\
\hline \multicolumn{5}{|c|}{ Total income } \\
\hline Income first quantile & $\begin{array}{l}-6.718^{* * *} \\
(0.711)\end{array}$ & $\begin{array}{l}-6.741^{* * *} \\
(0.606)\end{array}$ & & $\begin{array}{l}-6.792 * * * \\
(0.712)\end{array}$ \\
\hline Income second quantile & $\begin{array}{l}-3.420 * * * \\
(0.621)\end{array}$ & $\begin{array}{l}-3.416^{* * *} \\
(0.553)\end{array}$ & & $\begin{array}{l}-3.402 * * * \\
(0.622)\end{array}$ \\
\hline Income third quantile & $\begin{array}{l}-2.360 * * * \\
(0.567)\end{array}$ & $\begin{array}{l}-2.332 * * * * \\
(0.517)\end{array}$ & & $\begin{array}{l}-2.363^{* * *} \\
(0.567)\end{array}$ \\
\hline Income fourth quantile & $\begin{array}{l}-1.544^{* * * *} \\
(0.530)\end{array}$ & $\begin{array}{c}-1.526^{* * *} \\
(0.493)\end{array}$ & & $\begin{array}{l}-1.552^{* * *} \\
(0.530)\end{array}$ \\
\hline \multicolumn{5}{|c|}{ Non-farm income } \\
\hline $\begin{array}{l}\text { N. HH members employed in } \\
\text { off-farm agricultural sectors }\end{array}$ & $\begin{array}{l}2.433 * * * \\
(0.489)\end{array}$ & $\begin{array}{l}2.436^{* * *} \\
(0.427)\end{array}$ & $\begin{array}{l}2.141^{* * *} \\
(0.477)\end{array}$ & \\
\hline N. HH members employed in & $2.573 * * *$ & $2.607^{* * *}$ & $2.230 * * *$ & \\
\hline off-farm non-agricultural sectors & $(0.527)$ & $(0.424)$ & $(0.511)$ & \\
\hline \multicolumn{5}{|c|}{ Women's empowerment } \\
\hline $\begin{array}{l}\text { N. women members employed it } \\
\text { off-farm agricultural sectors }\end{array}$ & & & & $\begin{array}{l}0.936^{* *} \\
(0.404)\end{array}$ \\
\hline $\begin{array}{l}\text { N. women members employed in } \\
\text { off-farm non-agricultural sectors }\end{array}$ & & & & $\begin{array}{c}1.253^{* * *} \\
(0.394)\end{array}$ \\
\hline \multicolumn{5}{|c|}{ Use of income } \\
\hline Log food expenditure & & & $\begin{array}{l}1.842 * * * \\
(0.275)\end{array}$ & \\
\hline Log non-food expenditure & & & $\begin{array}{l}1.837 * * * \\
(0.290)\end{array}$ & \\
\hline Price index & $\begin{array}{c}0.015 \\
(0.014) \\
\end{array}$ & $\begin{array}{c}0.015 \\
(0.012) \\
\end{array}$ & $\begin{array}{c}0.013 \\
(0.014) \\
\end{array}$ & $\begin{array}{c}0.014 \\
(0.014) \\
\end{array}$ \\
\hline \multicolumn{5}{|c|}{ Seasonality } \\
\hline Hunger season & $\begin{array}{l}-3.695^{* * *} \\
(0.408)\end{array}$ & $\begin{array}{l}-3.632 * * * \\
(0.381)\end{array}$ & $\begin{array}{l}-3.475^{* * *} \\
(0.403)^{* * *}\end{array}$ & $\begin{array}{l}-3.772 * * * \\
(0.411)\end{array}$ \\
\hline _cons & $\begin{array}{c}70.091^{* * *} \\
(5.739)\end{array}$ & $\begin{array}{l}69.559 * * * \\
(6.957)\end{array}$ & $\begin{array}{l}40.208^{* * *} \\
(6.867)\end{array}$ & $\begin{array}{c}71.641 * * * \\
(5.732)\end{array}$ \\
\hline \multicolumn{5}{|c|}{ Sd of residuals and variance } \\
\hline sigma_u & 9.689 & 9.630 & 9.727 & 9.518 \\
\hline sigma_e & 11.964 & 11.915 & 11.825 & 11.986 \\
\hline Rho & 0.397 & 0.395 & 0.404 & 0.388 \\
\hline
\end{tabular}


Table 2. Cont.

\begin{tabular}{|c|c|c|c|c|}
\hline Variable & Model 1 & Model 2 & Model 3 & Model 4 \\
\hline \multicolumn{5}{|c|}{ F-statistic test } \\
\hline $\mathrm{F}$ & $16.64^{* * *}$ & $23.33^{* * *}$ & $18.230^{* * *}$ & $15.650^{* * *}$ \\
\hline \multicolumn{5}{|c|}{ R-sq } \\
\hline Within & 0.083 & 0.087 & 0.100 & 0.080 \\
\hline Between & 0.098 & 0.105 & 0.100 & 0.113 \\
\hline Overall & 0.084 & 0.089 & 0.093 & 0.090 \\
\hline \multicolumn{5}{|c|}{ Hausman specification test } \\
\hline $\begin{array}{l}\text { Hausman } \\
\text { chi2 }\end{array}$ & $106.67^{* * *}$ & $198.27^{* * *}$ & $148.99 * * *$ & $98.28^{* * *}$ \\
\hline
\end{tabular}

${ }^{*} p$-value $<0.10^{* *} p$-value $<0.05^{* * *} p$-value $<0.01$ (robust standard error). Source: author's elaboration based on primary sources of data.

Table 3. Fixed effects analysis of determinants of household FCS: Models 5-8.

\begin{tabular}{|c|c|c|c|c|}
\hline Variable & Model 5 & Model 6 & Model 7 & Model 8 \\
\hline \multicolumn{5}{|c|}{ Crop production } \\
\hline Number of crops harvested & $\begin{array}{c}2.002^{* * *} \\
(0.499)\end{array}$ & $\begin{array}{c}3.228^{* * *} \\
(0.523)\end{array}$ & $\begin{array}{c}1.689 * * * \\
(0.530)\end{array}$ & $\begin{array}{c}4.910 * * * \\
0.527\end{array}$ \\
\hline Number of crops harvested squared & $\begin{array}{c}-0.341^{* * *} \\
(0.117)\end{array}$ & $\begin{array}{c}-0.672 \text { *** } \\
(0.128)\end{array}$ & $\begin{array}{c}-0.446^{* * *} \\
(0.126)\end{array}$ & $\begin{array}{c}-0.383^{* * * *} \\
(0.122)\end{array}$ \\
\hline \multicolumn{5}{|c|}{$\mathrm{HH}$ agricultural assets } \\
\hline Production assets index & $\begin{array}{l}1.197^{* *} \\
(0.489)\end{array}$ & $\begin{array}{c}1.457 * * * \\
(0.500)\end{array}$ & $\begin{array}{c}1.441^{* * *} \\
(0.500)\end{array}$ & $\begin{array}{l}1.264^{* *} \\
(0.499)\end{array}$ \\
\hline Input use & $\begin{array}{c}-2.341^{* * *} \\
(0.642)\end{array}$ & $\begin{array}{c}-3.627^{* * *} \\
(0.661)\end{array}$ & $\begin{array}{c}-1.743^{* * *} \\
(0.645)\end{array}$ & $\begin{array}{l}-1.093 * \\
(0.659)\end{array}$ \\
\hline Savings & $\begin{array}{c}3.319 * * * \\
(0.644)\end{array}$ & $\begin{array}{c}3.115^{* * *} \\
(0.639)\end{array}$ & $\begin{array}{c}3.208^{* * * *} \\
(0.646)\end{array}$ & $\begin{array}{c}3.246^{* * *} \\
(0.647)\end{array}$ \\
\hline $\mathrm{HH}$ size adult equivalent & $\begin{array}{c}-1.286^{*} \\
(0.747)\end{array}$ & $\begin{array}{c}-2.358^{* * *} \\
(0.765)\end{array}$ & $\begin{array}{c}-2.045^{* * *} \\
(0.760)\end{array}$ & $\begin{array}{c}-1.397^{*} \\
(0.751)\end{array}$ \\
\hline Dependency ratio & $\begin{array}{c}0.039 \\
(0.026)\end{array}$ & $\begin{array}{l}0.049^{*} \\
(0.027)\end{array}$ & $\begin{array}{l}0.501 \text { * } \\
(0.027)\end{array}$ & $\begin{array}{l}0.044^{*} \\
(0.267)\end{array}$ \\
\hline Age & $\begin{array}{c}0.107 \\
(0.241)\end{array}$ & $\begin{array}{c}0.238 \\
(0.225)\end{array}$ & $\begin{array}{c}0.181 \\
(0.238)\end{array}$ & $\begin{array}{c}0.108 \\
(0.248)\end{array}$ \\
\hline Age squared & $\begin{array}{l}-0.002 \\
(0.002)\end{array}$ & $\begin{array}{c}-0.004 \text { * } \\
(0.002)\end{array}$ & $\begin{array}{l}-0.003 \\
(0.002)\end{array}$ & $\begin{array}{l}-0.002 \\
(0.002)\end{array}$ \\
\hline Gender & $\begin{array}{l}-1.740 \\
(2.374)\end{array}$ & $\begin{array}{l}-2.179 \\
(2.473)\end{array}$ & $\begin{array}{l}-1.969 \\
(2.390)\end{array}$ & $\begin{array}{l}-1.800 \\
(2.369)\end{array}$ \\
\hline Literacy & $\begin{array}{c}4.501 * * * \\
(1.139)\end{array}$ & $\begin{array}{c}4.887^{* * *} \\
(1.168)\end{array}$ & $\begin{array}{c}4.368^{* * *} \\
(1.158)\end{array}$ & $\begin{array}{c}4.306^{* * *} \\
(1.139)\end{array}$ \\
\hline Marital status & $\begin{array}{c}0.581 \\
(1.180)\end{array}$ & $\begin{array}{c}0.591 \\
(1.203)\end{array}$ & $\begin{array}{c}0.545 \\
(1.200)\end{array}$ & $\begin{array}{c}0.614 \\
(1.185)\end{array}$ \\
\hline Health status & $\begin{array}{c}-3.516^{* * *} \\
(0.700)\end{array}$ & $\begin{array}{c}-4.127^{* * *} \\
(0.702)\end{array}$ & $\begin{array}{c}-3.964^{* * *} \\
(0.695)\end{array}$ & $\begin{array}{c}-3.721^{* * *} \\
(0.697)\end{array}$ \\
\hline \multicolumn{5}{|c|}{ Use of crop production } \\
\hline Self-consumption & $\begin{array}{l}-0.809 \\
(0.812)\end{array}$ & $\begin{array}{c}0.274 \\
(0.962)\end{array}$ & $\begin{array}{c}-2.427^{* * *} \\
(0.749)\end{array}$ & $\begin{array}{c}-3.645^{* * *} \\
(0.810)\end{array}$ \\
\hline Market access & $\begin{array}{c}1.766 \\
(1.100)\end{array}$ & $\begin{array}{l}2.837 * \\
(1.683)\end{array}$ & $\begin{array}{l}2.618 \text { * } \\
(1.514)\end{array}$ & $\begin{array}{l}2.385^{*} \\
(1.235)\end{array}$ \\
\hline Market access * Number of crops harvested & $\begin{array}{l}-0.578 \\
(0.381)\end{array}$ & $\begin{array}{c}-0.936 \text { * } \\
(0.554)\end{array}$ & $\begin{array}{c}-0.918 \text { * } \\
(0.505)\end{array}$ & $\begin{array}{c}-0.875^{* *} \\
(0.434)\end{array}$ \\
\hline
\end{tabular}


Table 3. Cont.

\begin{tabular}{|c|c|c|c|c|}
\hline Variable & Model 5 & Model 6 & Model 7 & Model 8 \\
\hline \multicolumn{5}{|c|}{ Total income } \\
\hline Income first quantile & $\begin{array}{c}-7.007^{* * *} \\
(0.703)\end{array}$ & $\begin{array}{c}-6.595^{* * *} \\
(0.724)\end{array}$ & $\begin{array}{c}-6.683^{* * *} \\
(0.712)\end{array}$ & $\begin{array}{c}-6.989 * * * \\
(0.707)\end{array}$ \\
\hline Income second quantile & $\begin{array}{l}-3.354^{* * *} \\
(0.618)\end{array}$ & $\begin{array}{l}-3.098^{* * *} \\
(0.621)\end{array}$ & $\begin{array}{l}-3.245^{* * *} \\
(0.627)\end{array}$ & $\begin{array}{l}-3.477^{* * *} \\
(0.630)\end{array}$ \\
\hline Income third quantile & $\begin{array}{c}-2.222^{* * *} \\
(0.560)\end{array}$ & $\begin{array}{c}-2.137^{* * *} \\
(0.566)\end{array}$ & $\begin{array}{c}-2.203^{* * *} \\
(0.570)\end{array}$ & $\begin{array}{c}-2.268^{* * *} \\
(0.571)\end{array}$ \\
\hline Income fourth quantile & $\begin{array}{c}-1.503 * * * \\
(0.531)\end{array}$ & $\begin{array}{c}-1.504^{* * *} \\
(-0.531)\end{array}$ & $\begin{array}{c}-1.453^{* * *} \\
(0.536)\end{array}$ & $\begin{array}{c}-1.451^{* * *} \\
(0.540)\end{array}$ \\
\hline \multicolumn{5}{|c|}{ Non-farm income } \\
\hline $\begin{array}{l}\text { N. HH members employed in } \\
\text { off-farm agric. Sectors }\end{array}$ & $\begin{array}{c}2.468^{* * *} \\
(0.483)\end{array}$ & $\begin{array}{c}2.505^{* * *} \\
(0.502)\end{array}$ & $\begin{array}{c}2.372 * * * \\
(0.481)\end{array}$ & $\begin{array}{l}2.344^{* * *} \\
(0.478)\end{array}$ \\
\hline N. HH members employed in & $2.635^{* * *}$ & $2.902 * * *$ & $2.617^{* * *}$ & $2.524^{* * *}$ \\
\hline off-farm non-agric. Sectors & $(0.525)$ & $(0.542)$ & $(0.524)$ & $(0.520)$ \\
\hline Price index & 0.015 & 0.014 & 0.017 & 0.012 \\
\hline & $(0.014)$ & $(0.014)$ & $(0.014)$ & $(0.014)$ \\
\hline \multicolumn{5}{|c|}{ Seasonality } \\
\hline Maize harvesting & $5.972 * * *$ & & & \\
\hline Season & $(0.385)$ & & & \\
\hline Potatoes harvesting & & $-2.428^{* * *}$ & & \\
\hline Season & & $(0.685)$ & & \\
\hline Beans harvesting & & & $4.939 * * *$ & \\
\hline Season & & & $(0.457)$ & \\
\hline Other crops harvesting & & & & $-3.579 * * *$ \\
\hline Season & & & & $(0.268)$ \\
\hline _cons & $\begin{array}{l}68.619 * * * \\
(6.053)\end{array}$ & $\begin{array}{l}68.423 * * * \\
(5.751)\end{array}$ & $\begin{array}{l}68.858^{* * *} \\
(6.049)\end{array}$ & $\begin{array}{l}69.395^{* * *} \\
(6.260)\end{array}$ \\
\hline \multicolumn{5}{|c|}{ Sd of residuals and variance } \\
\hline sigma_u & 9.605 & 9.776 & 9.491 & 9.550 \\
\hline sigma_e & 11.827 & 12.004 & 11.905 & 11.844 \\
\hline Rho & 0.397 & 0.399 & 0.389 & 0.394 \\
\hline \multicolumn{5}{|c|}{ F-statistic test } \\
\hline $\mathrm{F}$ & $23.77^{* * *}$ & $14.310^{* * *}$ & $18.220^{* * *}$ & $21.29 * * *$ \\
\hline \multicolumn{5}{|c|}{ R-sq } \\
\hline Within & 0.100 & 0.073 & 0.088 & 0.097 \\
\hline Between & 0.107 & 0.091 & 0.119 & 0.112 \\
\hline Overall & 0.098 & 0.075 & 0.097 & 0.100 \\
\hline \multicolumn{5}{|c|}{ Hausman specification test } \\
\hline Hausman & & & & \\
\hline chi2 & $197.66^{* * *}$ & $169.61 * * *$ & $166.13^{* * *}$ & $182.10^{* * *}$ \\
\hline
\end{tabular}

${ }^{*} p$-value $<0.10^{* *} p$-value $<0.05^{* * *} p$-value $<0.01$ (robust standard error). Source: author's elaboration based on primary sources of data.

Based on the $\rho$ value, around 4 percent of the variance is due to differences across panels. The F-statistic tests whether all the coefficients in the model differ from zero. As its $p$-value is less than 0.05 in all our models, we reject this hypothesis. Therefore, all models are statistically significant. According to the $R$-squared values, the Model 3 estimators best explain the within variations $(R 2=0.100)$ while the Model 7 estimators best explain the between variations $(R 2=0.119)$. The Hausman test indicates that our fixed effect models provide consistent estimates as compared to the same estimations conducted with a random effects model. While all estimated parameters have the expected sign, 
not all are statistically significant. The majority of these estimators belong to the human capital endowment category.

Following Romeo et al. [21], we run our models with stepwise exclusion of the control variables that we considered relevant in the model specification. Removing these variables, the remaining associations with our dependent variable remained statistically significant thereby proving overall model robustness.

\subsection{Crop Diversification}

According to our results, the increase in the number of crops over time improves the household FCS up to a number of 2.5 crops and decreases this score thereafter. Therefore, our study confirms the inverse U-shaped relationship found in some studies exploring the association between agricultural and diet diversity [35,36]. As argued by Sibhatu et al. [35], a possible explanation for this trend lies in the forgone income from firm diversification beyond the optimal level. Our monthly data suggests a more articulated explanation of this relationship.

Figure 2 compares the average household FCS with the average number of crops harvested by household over the analysed period. From the figure, we can observe that the households in our sample use crop diversification during the months of relatively low levels of food insecurity (from March to June). This is a well-known trend in the literature, as suggested, for example, by Becquery et al. [13].

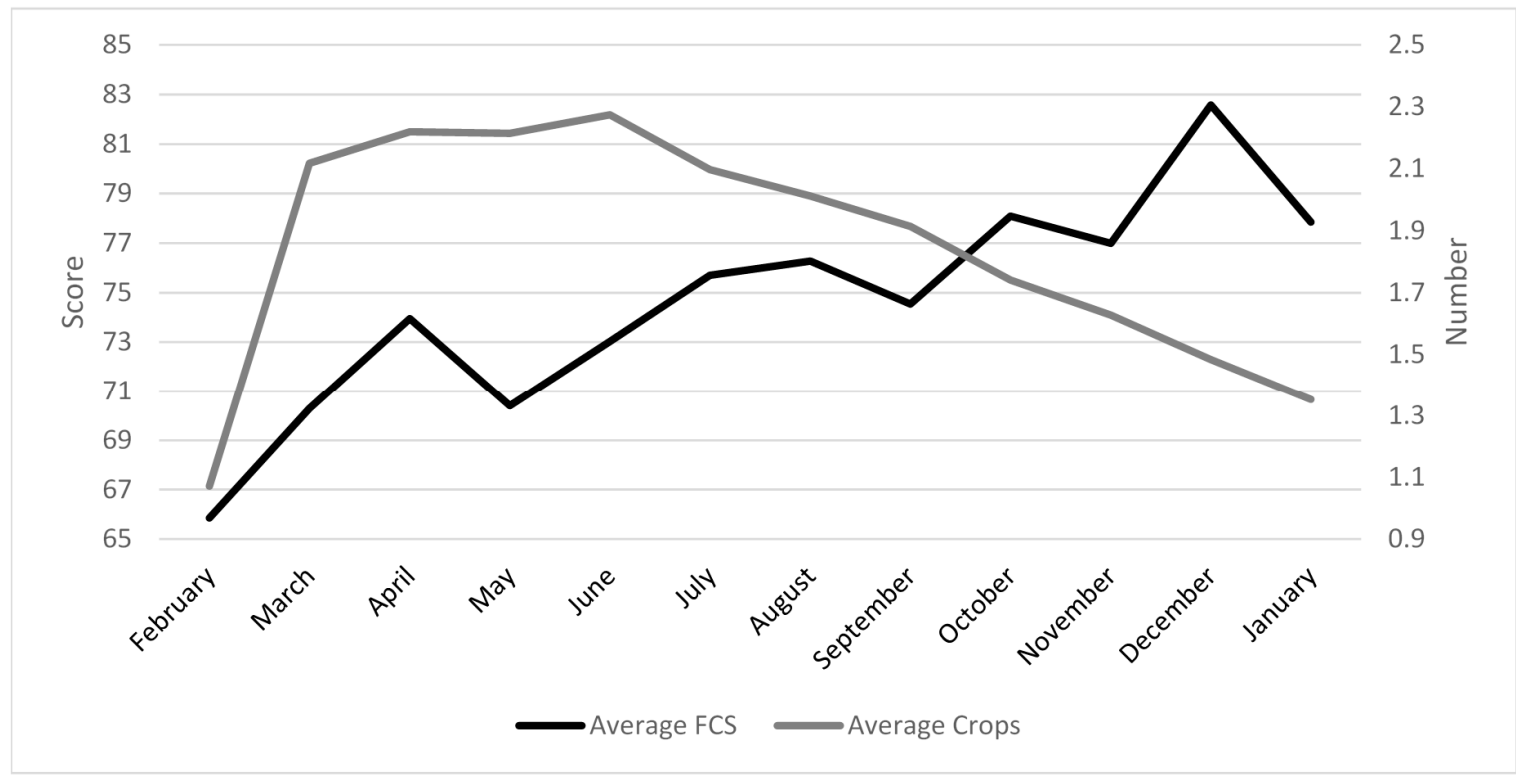

Figure 2. Average FCS and average number of crops produced by household (February 2018 to January 2019). Source: author's elaboration based on primary sources of data.

However, Figure 3 adds other important information for the understanding of the aforementioned effect. It shows the number of households harvesting the three most important crops, namely maize, beans, and potatoes, and the group of other crops. 


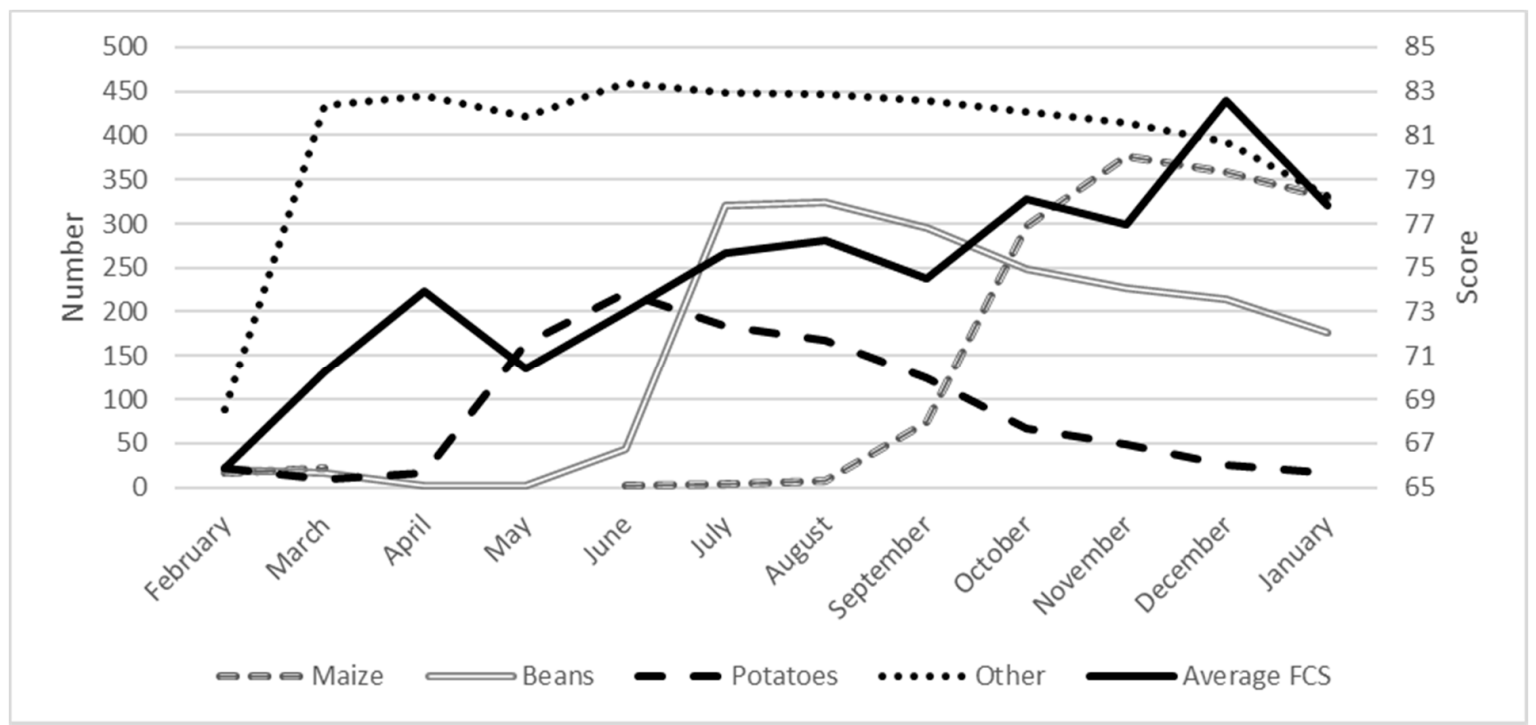

Figure 3. Number of households producing crops by type and average household FCS (February 2018 to January 2019). Source: author's elaboration based on primary sources of data.

The peak in the harvesting of the considered crops causes four consecutive waves due to the existence of only one main production season for the staple crops comprising maize, beans, and potatoes. At the beginning of the period analysed, when FCS is at its lowest and maize, beans, and potato production is very limited or absent, crop diversification towards the other crops starts and lasts until the mid-potato harvesting period. After the peak in potato harvesting, beans gathering commences with an improvement in the household food status, which further improves at the beginning of the maize-harvesting season. With beans harvesting, diversification towards other local crops reduces. According to the interviewed respondents, households use a part of the income earned from selling maize and beans to diversify their diet.

The estimation of the harvesting seasons provided in Table 3 captures these dynamics, with maize and beans as the only crops that are positively associated with the household FCS while potatoes and other crops are negatively associated with this score.

Therefore, crop diversification towards the local crops, even if important, is inadequate to support an improvement in FCS. The estimated coefficient for the hunger season confirms this observation. During this period, the FCS is between approximately 3.5 to 3.8 points lower than in the other periods.

\subsection{Use of Crop Production}

According to the literature, given a non-linear association between agricultural diversity and FCS, a household can improve its FCS through consumption from own production or by using the income from selling crops to purchase more diverse and better quality food. Based on our estimates, the household's self-consumption orientation is negatively associated with the FCS. This is because the share of consumption of one's own production reaches its maximum value during the hunger season and immediately thereafter. During the focus group discussions, interviewed participants declared that, during this period, they produce local food crops mainly for subsistence and hence, have little possibility to sell their produce. The dependence on the market for purchasing food items is high during this period. They also observed that income from selling these local crops is limited and less profitable especially when compared with maize and beans, grown mainly for commercial purposes. Moreover, during the period investigated, the Lake Naivasha basin has suffered from drought that has further compromised productivity, especially of the majority of small farmers with a very limited access to the lake as source of irrigation [16].

This situation, justifies the positive, even if statistically weak, relationship between the level of commercialisation and FCS also found in the literature [7]. However, the importance of the household's 
maize market followed by beans market orientation for food security emerges, introducing in our estimated model the market access by crop (Model 2). Therefore, in our case, this association has a strong seasonal component. Our focus group discussions further confirm that farmers sell maize and beans immediately after the harvest, when prices are low, due to a lack of crop storage facilities. Moreover, most of these high-value crops are sold to middlemen or traders; only a small proportion reaches the local markets.

Another interesting aspect highlighted by our analysis is the statistically significant association between the interaction term (market access*number of crops harvested) and FCS. The estimated negative sign of this variable suggests that household farm commercialization reduces the importance of farm diversity in increasing household FCS. As explained above, this is the result of a diversification strategy linked to the absence of maize and beans outside their production period.

\subsection{Income and Food and Non-Food Expenditure}

As expected, in the rural Lake Naivasha basin, wealth is a key determinant of food security status thereby confirming the evidence presented in the literature [21]. Households in the bottom quantile of the consumption expenditure distribution have almost a six point lower FCS, on average, compared to households in the wealthiest quantile. This gap reduces significantly at higher income quantiles.

According to our results, off-farm income has important implications for food security; the number of household members employed in off-farm activities is positively associated with FCS, regardless of their specific sectors of employment. For every additional member employed in the off-farm agricultural or non-agricultural sector, the FCS increases by more than 2 points. However, the strength of this positive association weakens if female household members are in off-farm employment with corresponding estimated coefficients of 0.936 and 1.253 for off-farm employment in the agriculture and non-agriculture sectors, respectively. A possible explanation for this lower coefficient suggested during our focus group discussions is the fact that women are generally involved in the lower paid sectors. Moreover, the gender pay gap reflects the inequalities between the wages of male and female employees in all sectors.

The focus group discussions confirmed the 'push' and 'pull' factors motives for households to diversify income as suggested by Barret et al. [37]. In the investigated area, households adopt income diversification strategies as a self-insurance tool and as a means to reduce consumption risks, especially during the hunger season or when the agricultural sector does not absorb the labour force. During these periods, household members search for casual jobs, especially in the floricultural sector. Casual labour is of special importance because it allows supporting household livelihood when farmers are waiting for their crops to mature and agricultural labour is not required, as well as to avail of the labour force when it is necessary for agriculture.

Figure 4 clearly depicts this situation. It shows the average number of household members employed in non-farm agricultural and non-agricultural sectors by month. The peak in the household members employed in the agricultural sector is during the planting season in March and April, the weeding period at the end of April and beginning of May, and the maize-harvesting season in October and November. In other periods, labour demand in the agricultural sector is limited and livelihood depends mainly on casual labour outside this sector, especially in the floricultural sector. However, we note that, despite the floricultural sector providing at least the compulsory minimum salary to casual workers, the adult equivalent computations suggest that it is often below the food poverty line. Therefore, agricultural income compensates for this gap, making this activity strategic for household food security.

In some cases, we note that off-farm jobs relate to the realisation of strategic complementarities between crop production and other activities such as small businesses or shops. While this short value-chain has a high potential to positively affect household income, currently it remains underutilised. During the focus group discussions, participants declared their lack of ability to set up a business as one of the major constraints in performing to their full potential. 


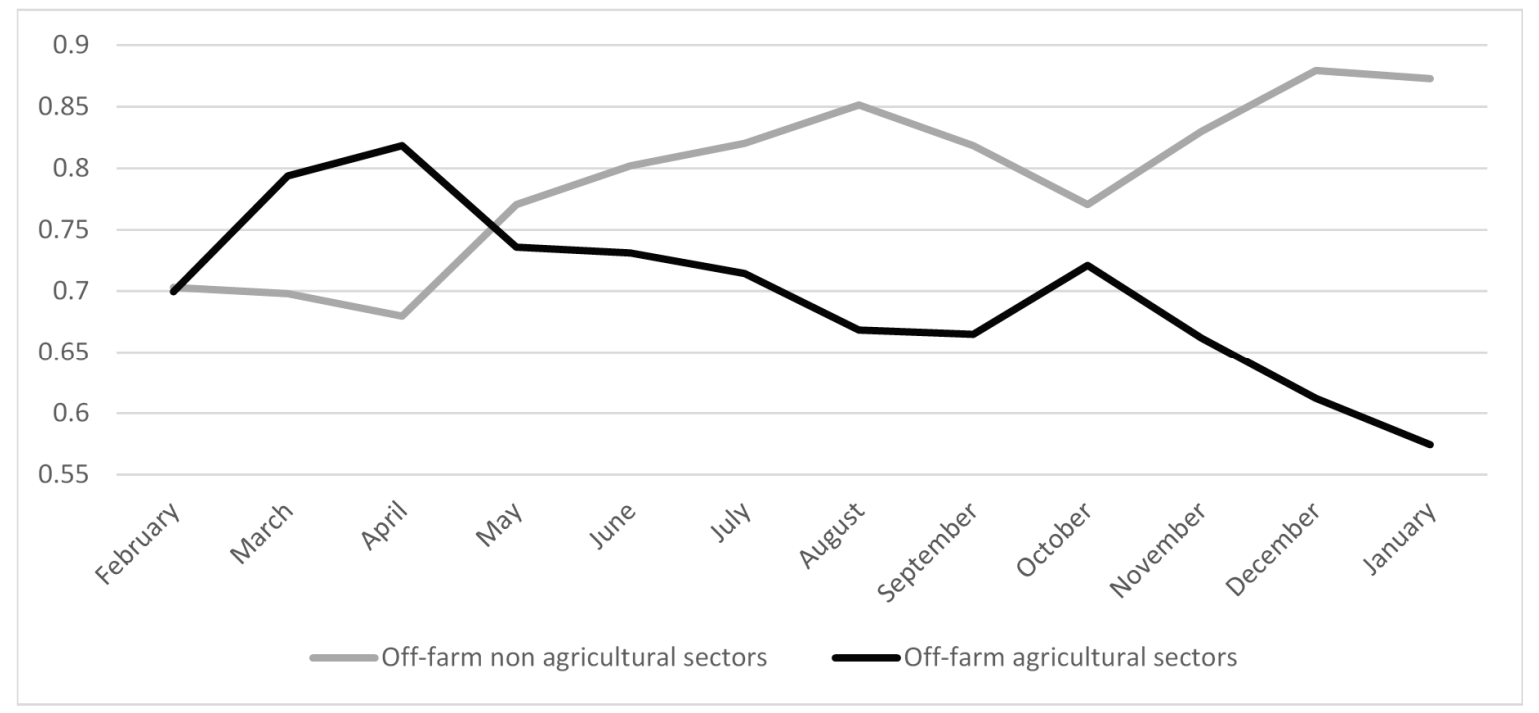

Figure 4. Average number of household members employed in off-farm agricultural and non-agricultural sectors by month (February 2018 to January 2019). Source: author's elaboration based on primary sources of data.

\subsection{Household Agricultural Assets}

Our analysis confirms the positive role of households' agricultural assets on food security found in the literature (see, for example, [38,39]). In the investigated area, the average effect over time of intangible capital and literate head is strongly statistically and positively associated to FCS within households. Households that save have an FCS that is around three points higher than those that do not. Similarly, when the head is literate, the household FCS is four points higher than when the head is illiterate. For illiterate workers, access to better-paying jobs is constrained. By contrast, most educated workers can further diversify their income in sectors such as merchant and trade, and transport and services, where they can even develop their own small businesses.

Labour availability within the household, measured by the household size per adult equivalent, is also statistically significant and positively associated with the household FCS. Given this result, the negative and strongly statistically significant association of health status to household FCS is unsurprising. This relationship is linked to the seasonal dynamic of health problems. According to our data, health issues are relevant in the Lake Naivasha Basin where almost 20 percent of all households have at least one member with a chronic disease and around 30 percent of them have at least one member who is affected by a transitory health problem during the period from February to April, representing the long rainy season, against the almost 3 percent in the period from November to January. When households have members with a health problem, their FCS reduces by around four points. In a labour intensive system such as that prevailing in the investigated area, during the focus group discussions, all participants highlighted that the effect of a health problem on food security is accentuated by the loss of the work force and related income. Moreover, when sick individuals need to be hospitalised, the cost of the health services is relatively much higher than their income such that they often reduce food expenditure, with a corresponding deterioration in their diet quality.

Concerning production assets, the specific index result is statistically significant and positively correlated to household FCS while input use presents a negative sign. During our focus group discussions, we designed the seasonal and crop calendar for the investigated area. According to the collected information, the main sowing season is from March to May when FCS is relatively low, with a second sowing season in October and November, but subject to rain. As shown in Figure 5, during the main sowing season, input use is at its peak. 


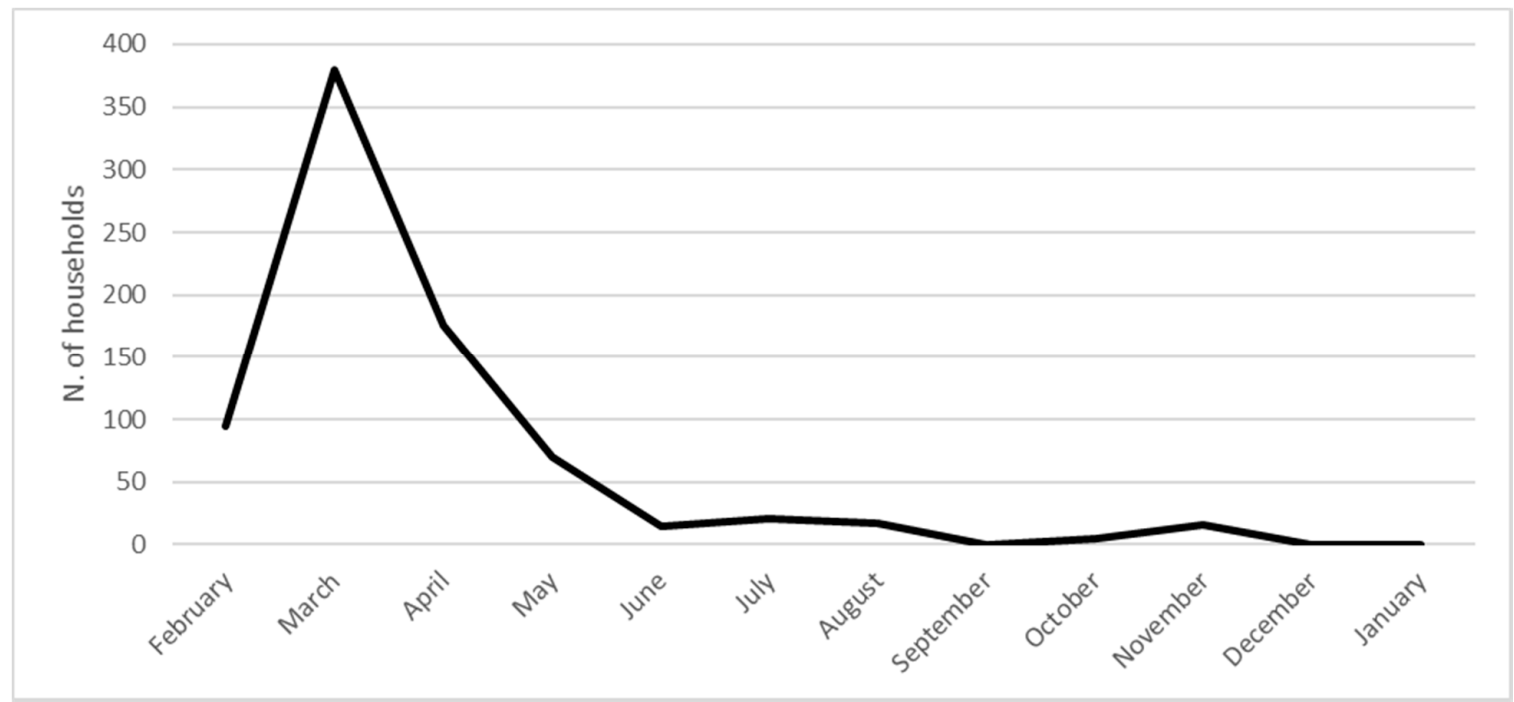

Figure 5. Number of households using agricultural inputs by month (February 2018 to January 2019). Source: author's elaboration based on primary sources of data.

Therefore, the direction of the association does not suggest a reduction in the use of inputs to improve household FCS; it is a result of the overlapping sowing and hunger seasons. However, the main sowing season is during the period when households' food security status is most vulnerable and fragile; they depend on the market for food and need to invest capital in the agricultural sector in this period.

\section{Conclusions}

Our study investigated the role of seasonality within the debate of nutrition-sensitive agriculture considering the pathways of food, income, and women's empowerment, through which the sector affects nutrition in the specific case of the rural Lake Naivasha Basin. In all the forms introduced in our analysis, seasonality emerged as an important dimension for understanding the link between agriculture and nutrition, adding to the literature in several ways.

First, the literature suggests that the production of a wider range of food groups can improve food security through a more diversified diet. We noted that this problem is more complex in the rural Lake Naivasha Basin and involves both the typology of crops produced over the year and how these are used by the households. These features also explain the inverse U-shaped association between crop diversity and household FCS over the year. In the investigated area, the FCS improves when households harvest and partly sell maize and beans. Before this period, crop diversification towards local species is primarily a survival strategy and the households mainly consume what they produce. However, local crop diversification and self-consumption are not enough to guarantee a nutritional status level that is comparable to that during the maize- and beans-harvesting season. This situation suggests the need to overcome the policy dilemma highlighted by Devereux and Loughurst [40] and to design an effective combination of interventions aimed at boosting income and consumption in farming households.

One of the most important determinants of the dual seasonal behaviour of households is the existence of a dominant rain-fed agricultural system whose negative effects are today exacerbated by erratic and unpredictable rainfall. Therefore, it is necessary to have an effective and integrated blue (Lake Naivasha) and green (rain) water-management system to grow a second harvest, increase the productivity of counter-seasonal sources of food and income, and reduce the risk of loss of food produce. While there is existing knowledge on how to improve water exploitation, it requires relevant investment in infrastructure, technology, and environmental safeguard measures. Based on the 
evidence of sub-Saharan Africa, with irrigation farmers usually grow second and often higher-value crops with positive effects on livelihood and food security [41].

Training farmers in soil and water conservation practices, supporting the introduction of tolerant varieties, and better exploitation of landscape variability based on improved knowledge of land and land use, appears to be another key option to strengthen their capacity to adapt to and cope with the drought season.

Moreover, a guaranteed harvest reduces the risk of technological investments, such as fertilisers, which can boost productivity [41]. According to our results, technology adoption is a critical issue in the investigated area because of the overlapping sowing period and the hunger season, when households depend on the market to purchase food and are not producing lucrative crops. The poorest and food-insecure households have little opportunities to invest in this direction and deserve specific pro-poor farm capital allocation especially on a seasonal basis as well as agricultural extension services, institutions, and regulations to guarantee a supportive environment for technology adoption and productivity improvement. However, the literature suggests that improved technology may increase rather than reduce the extent of income seasonality [42]. Therefore, the effects of this process should be monitored carefully and, in case of negative implications on households' food and nutritional status, combined with appropriate consumption smoothing mechanisms [43].

The establishment of a crop storage facility at the local market level and the enhancement of the markets for local food products are other counter-seasonal strategies with possible positive effects on food and nutrition security suggested by our analysis. Concerning local products, attention should be focused on their promotion and marketing with the aim of stimulating the commercialization of smallholder farmers. More generally, local crops diversification and commercialization can be a synergistic strategy with a significant and positive impact on household food and nutrition security.

According to our study, household FCS has important interactions with wealth and, in this context, also with the off-farm income, which is primarily used as a form of safety net in periods when agricultural labour demand is lacking. This result highlights the importance of accounting for labour requirements and employment opportunities in the design of nutrition-sensitive agricultural policies and of linking the sector to social protection.

Training farmers on how to do business is another important result of our analysis. In this respect, coordination between the floriculture sector and the extension workers can successfully strengthen farmers' capacity to adapt and cope with drought and to diversify their production and income. Some households in our sample reported the need for a larger intervention by agricultural extension workers to allow them to adopt new methods of farming and to advise them on animal production. However, the involvement of the private sector is also important. This should go beyond training to include supervision during the production phases, favouring technological transfer to local communities. Possible forms of out-grower floriculture or vegetables by smallholder farmers should be also evaluated.

Another important link for household food and nutrition security is between agriculture and health. For this purpose, our results suggest integrating access to preventive and curative health services in the design of agricultural policies for food and nutrition security, with specific attention to the hunger season.

Our study also indicates the limits of the available data. The importance of agricultural seasonality for the development of nutrition-sensitive agriculture makes locally contextualised data collection on a monthly basis a priority. Neglecting the phenomena due to lack of information makes it challenging to design and monitor the effectiveness of relevant policies and programmes. Moreover, the intra-household dynamics over a year deserve specific attention in order to understand whether seasonal dynamics affect individual family members' nutritional status in different ways and this is one of the future directions of our investigation. 
Funding: This research was funded by the Italian Ministry of Education, University and Research within the Sustainable Agrifood Systems Strategies (SASS) project awarded as of relevant national interest [Delibera $\mathrm{n}$. 71/2016 (17A01736) GU Serie Generale n. 56 del 08-03-2017].

Conflicts of Interest: The author declares no conflict of interest.

\section{References}

1. Hodge, J.; Herforth, A.; Gillespie, S.; Beyero, M.; Wagah, M.; Semakula., R.M. Is There an Enabling Environment for Nutrition-Sensitive Agriculture in East Africa? Stakeholder Perspectives from Ethiopia, Kenya, and Uganda. Food Nutr. Bull. 2015, 36, 503-519. [CrossRef] [PubMed]

2. FAO. Improving Diets through Nutrition-Sensitive Agriculture. 2014. Available online: http://www.fao.org/ about/meetings/icn2/news/news-detail/en/c/261494/ (accessed on 1 October 2019).

3. United Nations. Resolution Adopted by the General Assembly on 25 September 2015. Transforming Our World: The 2030 Agenda for Sustainable Development. 2015. Available online: https://www.un.org/ga/ search/view_doc.asp?symbol=A/RES/70/1\&Lang=E (accessed on 1 October 2019).

4. Rampa, F.; van Seters, J. Toward the Development and Implementation of CAADP Regional Compacts and Investment Plans: The State of Play; European Center for Development Policy Management (ECDPM): Maastricht, The Netherlands, 2013.

5. Ruel, M.T.; Quisumbinga, A.R.; Balagamwala, M. Nutrition-sensitive agriculture: What have we learned so far? Glob. Food Secur. 2018, 17, 128-153. [CrossRef]

6. Carletto, C.; Ruel, M.; Winters, P.; Zezza, A. Farm-level pathways to improved nutritional status: Introduction to the special issue. J. Dev. Stud. 2015, 51, 945-957. [CrossRef]

7. Jones, A.D. Critical review of the emerging research evidence on agricultural biodiversity, diet diversity, and nutritional status in low- and middle-income countries. Nutr. Rev. 2017, 75, 769-782. [CrossRef]

8. Leroy, J.L.; Ruel, M.; Frongillo, E.A.; Harris, J.; Ballard, T.J. Measuring the Food Access Dimension of Food Security: A Critical Review and Mapping of Indicators. Food Nutr. Bull. 2015, 36, 167-195. [CrossRef]

9. Sassi, M. Economic and health determinants of child nutritional status in the Malawian district of Salima. Eur. J. Dev. Res. 2014, 26, 761-782. [CrossRef]

10. Sassi, M. Seasonality and Trends in Child Malnutrition: Time-Series Analysis of Health Clinic Data from the Dowa District of Malawi. J. Dev. Stud. 2015, 51, 1667-1682. [CrossRef]

11. Hirvonen, K.; Taffesse, A.S.; Worku Hassen, I. Seasonality and household diets in Ethiopia. Public Health Nutr. 2016, 19, 1723-1730. [CrossRef]

12. Ayenew, H.Y.; Biadgilign, S.; Schickramm, L.; Abate-Kassa, G.; Sauer, J. Production diversification, dietary diversity and consumption seasonality: Panel data evidence from Nigeria. BMC Public Health 2018, 18, 988.

13. Becquey, E.; Delpeuch, F.; Konaté, A.M.; Delsol, H.; Lange, M.; Zoungrana, M.; Martin-Prevel, Y. Seasonality of the dietary dimension of household food security in urban Burkina Faso. Br. J. Nutr. 2012, 107, 1860-1870. [CrossRef]

14. Ecker, O. Agricultural transformation and food and nutrition security in Ghana: Does farm production diversity (still) matter for household dietary diversity? Food Policy 2018, 79, 271-282. [CrossRef]

15. Pinstrup-Andersen, P. Can agriculture meet future nutrition challenges? Eur. J. Dev. Res. 2013, 25, 5-12. [CrossRef]

16. Ghawana, T. Flowering Economy of Naivasha. Impacts of Major Farming Systems on the Local Economy; International Institute for Geo-Information Science and Earth Observation Enschede: Enschede, The Netherlands, 2008.

17. Fan, S.; Yosef, S.; Pandya-Lorch, R. Seizing the Momentum to Reshape Agriculture for Nutrition. In Agriculture for Improved Nutrition: Seizing the Momentum; Fan, S., Yosef, S., Pandya-Lorch, R., Eds.; CAB International: Boston, MA, USA, 2019; pp. 1-15.

18. Headey, D.; Chiu, A.; Kadiyala, S. Agriculture's Role in the Indian Enigma: Help or Hindrance to the Undernutrition Crisis? IFPRI Discussion Paper 01085; International Food Policy Research Institute: Washington, DC, USA, 2011.

19. Hoddinot, J.; Headey, D.; Dereje, M. Cows, Missing Milk Markets, and Nutrition in Rural Ethiopia. J. Dev. Stud. 2015, 51, 958-975. [CrossRef]

20. Ruel, M. Is Dietary Diversity an Indicator of Food Security or Dietary Quality? A Review of Measurement Issues and Research Needs; FCND Discussion Paper n. 140; International Food Policy Research Institute: Washington, DC, USA, 2002. 
21. Romeo, A.; Meerman, J.; Demeke, M.; Scognamillo, A.; Asfaw, S. Linking farm diversification to household diet diversification: Evidence from a sample of Kenyan ultra-poor farmers. Food Secur. 2016, 8, 1069-1085. [CrossRef]

22. Sassi, M. Understanding Food Insecurity. Key Features, Indicators, and Response Design; Springer: Berlin, Germany, 2018.

23. WFP, Vulnerability Analysis and Mapping. Food Consumption Analysis Calculation and Use of the Food Consumption Score in Food Security Analysis; United Nations World Food Programme: Rome, Italy, 2008.

24. Jones, A.D.; Shrinivas, A.; Bezner-Kerr, R. Farm production diversity is associated with grater household dietary diversity in Malawi: Findings from nationally representative data. Food Policy 2014, 46, 1-12. [CrossRef]

25. Coates, J.; Lorge Rogers, B.; Webb, P.; Maxwell, D.; Houser, R.; McDonald, C. Diet Diversity Study; World Food Programme, Emergency Needs Assessment Service (ODAN): Rome, Italy, 2007.

26. Wiesmann, D.; Bassett, L.; Benson, T.; Hoddinott, J. Validation of the World Food Programme's Food Consumption Score and Alternative Indicators of Household Food Security; IPRI Discussion Paper 00870; International Food Policy Research Institute (IFPRI): Washington, DC, USA, 2009.

27. Islam, A.H.M.S.; von Brown, J.; Thorne-Luman, A.L.; Ahmed, A.U. Farm diversification and food and nutrition security in Bangladesh: Empirical evidence from nationally representative household panel data. Food Secur. 2018, 10, 701-720. [CrossRef]

28. Koppmair, S.; Kassie, M.; Qaim, M. Farm production, market access and dietary diversity in Malawi. Public Health Nutr. 2016, 20, 325-335. [CrossRef]

29. Hagenaars, A.; de Vos, K.; Zaidi, M.A. Poverty Statistics in the Late 1980s: Research Based on Micro-Data; Office for Official Publications of the European Communities: Luxembourg, 1994.

30. Pitt, M.M.; Rosenzweig, M.R. Health and Nutrient Consumption Across and Within Farm Households. Rev. Econ. Stat. 1985, 67, 212-223. [CrossRef]

31. Arias, P.; Hallam, D.; Krivinos, E.; Morrison, J. Smallholder Integration in Changing Food Markets; FAO: Rome, Italy, 2013.

32. Poole, N. Smallholder Agriculture and Market Participation; Food and Agriculture Organization of the United Nations and Practical Action Publishing: Rome, Italy, 2017.

33. Cochran, W.G. Sampling Techniques, 3rd ed.; John Wiley \& Sons: New York, NY, USA, 1997.

34. KNBS. Kenya Demographic and Health Survey, 2014; Kenya National Bureau of Statistics: Nairobi, Kenya, 2014.

35. Sibhatu, K.T.; Krishna, V.V.; Qaim, M. Production diversity and dietary diversity in smallholder farm households. Proc. Natl. Acad. Sci. USA 2015, 112, 10657-10662. [CrossRef]

36. Pellegrini, L.; Tasciotti, L. Crop diversification, dietary diversification and agricultural income: Empirical evidence from eight developing countries. Can. J. Dev. Stud. 2014, 35, 211-227. [CrossRef]

37. Barrett, C.B.; Reardon, T.; Webb, P. Nonfarm income diversification and household livelihood strategies in rural Africa: Concepts, dynamics, and policy implications. Food Policy 2001, 26, 315-331. [CrossRef]

38. Oke, A.; Walumbwa, F.; Yan, T.; Idiagbon-Oke, M.; Ojode, L.A. Linking economic status with technology adoption in three emerging economies of Sub-Saharan Africa. J. Manuf. Technol. Manag. 2014, 25, 49-68. [CrossRef]

39. Sohoulande Djebou, D.C.; Price, E.; Kibriya, S.; Ahn, J. Comparative Analysis of Agricultural Assets, Incomes and Food Security of Rural Households in Ghana, Senegal and Liberia. Agriculture 2017, 7, 38. [CrossRef]

40. Devereux, S.; Longhurst, R. Incorporating Seasonality into Agricultural Project Design and Learning. IDS Bull. 2010, 41, 88-95. [CrossRef]

41. Abrams, L. Unlocking the Potential of Enhanced Rainfed Agriculture; Report no. 39; SIWI: Stockholm, Sweden, 2018.

42. Nwachukwu, J.U. Technology Adoption and Agricultural Development in Sub-Saharan Africa (SSA): A Nigerian Case Study. Cult. Relig. Stud. 2017, 5, 371-385.

43. Khandker, S.R.; Mahmud, W. Seasonal Hunger and Public Policies: Evidence from Northwest Bangladesh; The World Bank: Washington, DC, USA, 2012.

(C) 2019 by the author. Licensee MDPI, Basel, Switzerland. This article is an open access article distributed under the terms and conditions of the Creative Commons Attribution (CC BY) license (http://creativecommons.org/licenses/by/4.0/). 